\title{
Callery Pear Cultivars Tested As Street Trees: Final Report on a 12-year Study
}

\author{
Henry D. Gerhold
}

\begin{abstract}
Cooperators in the Municipal Tree Restoration Program planted nine Callery pear (Pyrus calleryana Decne.) cultivars in 11 Pennsylvania, U.S. communities for evaluation as street trees, comparing two cultivars (three in one case) in each community. Cooperators measured them annually with standardized methods for 3 years and then at 3-year intervals until the 12th year. The most noteworthy differences occurred in tree height and crown width. The tallest were Aristocrat ${ }^{\mathrm{TM}}$, 'Cleveland Select', and 'Redspire', attaining more than $8 \mathrm{~m} \mathrm{(26} \mathrm{ft)} \mathrm{on} \mathrm{average} \mathrm{by} \mathrm{the} \mathrm{twelfth} \mathrm{year} \mathrm{and} \mathrm{even} 10.3 \mathrm{~m}(34 \mathrm{ft})$ in one community. 'Autumn Blaze', evaluated only at one location, was $\approx 1.5$ to $2 \mathrm{~m}$ ( 5 to $6.6 \mathrm{ft}$ ) shorter in the 12 th year. Heights of the other cultivars, tested at just one or two locations, were similar to the tallest ones. Crown widths differed more in the first 9 years than at the twelfth when on average most were $\approx 6.5 \mathrm{~m}(21.5 \mathrm{ft})$ wide. Cleveland Pride ${ }^{\circledR}$, 'Cleveland Select', Valiant ${ }^{\circledR}$, and 'Whitehouse' were narrower than the others until the ninth year, but only 'Cleveland Select' at $\approx 5.6$ $\mathrm{m}(18.5 \mathrm{ft})$ remained narrower in the twelfth year and not everywhere. All cultivars were in good health during the whole period, although the foliage of 'Whitehouse' exhibited minor injuries in many years. As street trees, the Callery pears were not invasive and did not yet experience branch breakage, which can become a serious problem. All of the cultivars are too tall to be planted under utility wires.
\end{abstract}

Key Words. Callery pear cultivars; performance testing; Pyrus calleryana; street tree evaluation.

This final report brings to a conclusion a series of evaluations of nine Callery pear (Pyrus calleryana) cultivars planted in Pennsylvania, U.S. as street trees. Two previous reports (Gerhold and McElroy 1994; Gerhold 2000) provided preliminary data up to 9 years after planting, and results have now been extended to the twelfth year. Performance test plantings of the Municipal Tree Restoration Program (MTRP), which include many more species and localities, have encouraged municipalities to improve their tree programs. The test plantings serve as demonstrations of utility-compatible trees, and results provide information helpful for selecting appropriate cultivars that can be planted under utility wires.

Callery pears have been quite popular after introduction of the 'Bradford' cultivar in 1963 as a result of their attractive flowers and foliage, and tolerance of urban conditions. Their features as landscape trees have been evaluated in various locations, including Alabama (Fare et al. 1991), New Jersey (Kuser et al. 2001), and Ohio (Haserodt and Sydnor 1983).

\section{MATERIALS AND METHODS}

\section{Plants and Experimental Design}

Cooperators planted the nine Callery pear cultivars in 11 Pennsylvania communities during 1988 to 1993. Community representatives chose the planting sites with the advice of utility foresters, service foresters in the Bureau of Forestry, or Penn State extension urban foresters.

Each test planting in a community consisted of two paired cultivars, except in Tioga where there were three. A typical test consisted of two cultivars planted alternately within 4 to 10 plots that contained 4 to 16 trees each for a total of 50 trees. All test trees were planted along streets and under electric conductors. The utility company arranged for the removal of large trees in the plots that interfered with utility lines, thus making space for planting in some of the plots.

\section{Plant Materials}

The test trees came from several nurseries as balled-andburlapped stock, and the same nursery always supplied both cultivars for a community. Calipers ranged from 4.4 to $5.1 \mathrm{~cm}$ ( 1.76 to $2 \mathrm{in}$ ) and heights from 2.8 to $5.0 \mathrm{~m}(9.2$ to $16.5 \mathrm{ft})$. The wide range in heights presumably could be explained by genetic differences among cultivars and diverse cultural differences among nurseries that supplied the trees. 'Redspire' typically was 0.2 to $0.6 \mathrm{~m}(0.7$ to $2 \mathrm{ft})$ taller than its companion cultivar; 'Cleveland Select' planting stock tended to be shorter but not in all cases.

No unusual climatic events occurred during the study. Wet snow or ice before leaf-fall can cause devastating branch 
breakage in this species, but none was reported at any of the study sites.

\section{Measurements and Analysis}

A trained cooperator inspected and measured the trees soon after planting, then annually during the first 3 years, and at 3 -year intervals afterward. During September or October, a service forester or extension urban forester, using standardized procedures, measured tree height, trunk diameter, and crown width; classified the health of foliage, branches, and trunk separately; and rated maintenance needs and overall quality. The health of foliage and branches was estimated according to the percentage injured using a 5-point scale: $1=$ 65 to $100,2=45$ to $60,3=25$ to $40,4=5$ to $20,5=<5$. The scale for trunk injuries was $1=$ tree dead, $2=$ severe injuries, $3=$ moderate, $4=$ slight, $5=$ no injuries. Causes of injuries such as by diseases, insects, drought, or mechanical damage were identified and recorded when possible.

An analysis of variance (using MINITAB's General Linear Model) of quantitative data collected in a given year calculated means and determined statistical differences between cultivars at the 5\% level of probability. Each test location in every year constituted a separate experiment with plots providing replication within a community. These results, along with comments provided by cooperators, were used to characterize performance of the cultivars.

\section{RESULTS}

The most extensive information was obtained for Aristocrat (in four communities), 'Cleveland Select' (in seven), and 'Redspire' (in four) (Table 1). These three cultivars turned out to be the tallest after the third year (Figure 1); their average heights in the 12 th year were $\approx 8.5 \mathrm{~m}(28 \mathrm{ft})$. 'Autumn Blaze' at $6.7 \mathrm{~m}(22 \mathrm{ft})$ was the shortest, although evaluated in

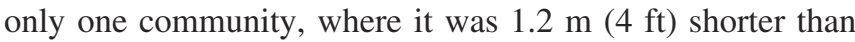
'Redspire'. The other cultivars, evaluated in one or two communities, were in most cases similar in height or not quite as tall as the largest cultivars.

The average crown widths of some cultivars differed by $\approx 2$ $\mathrm{m}(6.6 \mathrm{ft})$ through the sixth year (Figure 2), but most converged at $\approx 6$ to $7 \mathrm{~m}$ (19.8 to $23 \mathrm{ft}$ ) in the 12th year (Table 1 ). 'Cleveland Select' was narrower, most commonly between 5

Table 1. Size and health ratings of Callery pear cultivars, planted as street trees, two or three cultivars paired in each community ${ }^{2}$.

\begin{tabular}{|c|c|c|c|c|c|c|c|}
\hline Cultivar/abbreviation & Paired cultivar & Year & $\begin{array}{l}\text { Diam. } \\
(\mathrm{cm})\end{array}$ & $\begin{array}{l}\text { Ht. } \\
(\mathrm{m})\end{array}$ & $\begin{array}{l}\text { Width } \\
\text { (m) }\end{array}$ & $\begin{array}{l}\text { Foliage } \\
\text { (1 to } 5)\end{array}$ & $\begin{array}{l}\text { Branches } \\
\text { (1 to } 5 \text { ) }\end{array}$ \\
\hline \multirow[t]{4}{*}{ Aristocrat ${ }^{\mathrm{TM}} / \mathrm{Ar}$} & $\mathrm{Rd}$ & 12 & $22.8^{y}$ & 8.68 & 6.00 & 4.9 & 4.8 \\
\hline & $\mathrm{CS}, \mathrm{Rd}$ & 12 & $23.3^{y}$ & 10.30 & 7.29 & 4.3 & 4.5 \\
\hline & $\mathrm{CS}$ & 12 & 24.1 & 7.65 & 6.88 & 4.1 & 4.5 \\
\hline & CS & 12 & 21.6 & 8.35 & $5.91^{\mathrm{y}}$ & 4.1 & 4.7 \\
\hline 'Autumn Blaze'/AB & $\mathrm{Rd}$ & 12 & 18.6 & $6.65^{x}$ & 7.37 & 4.7 & 4.3 \\
\hline 'Bradford'/Br & Wh & 12 & $23.3^{y}$ & 8.84 & $7.71^{\mathrm{y}}$ & $4.6^{\mathrm{y}}$ & 4.5 \\
\hline 'Capital'/Ca & $\mathrm{CS}$ & 10 & $20.9^{y}$ & $6.97^{y}$ & 6.46 & 4.9 & 4.7 \\
\hline Cleveland Pride ${ }^{\circledR} / \mathrm{CP}$ & $\mathrm{CS}$ & 12 & 17.4 & $6.97^{x}$ & $6.64^{\mathrm{y}}$ & 4.9 & 5.0 \\
\hline \multirow[t]{7}{*}{ 'Cleveland Select'/CS } & Wh & 12 & 17.6 & $8.78^{y}$ & 5.49 & $4.7^{y}$ & 4.6 \\
\hline & Ar, Rd & 12 & $15.6^{\mathrm{x}}$ & 10.00 & 6.34 & 4.5 & 4.7 \\
\hline & $\mathrm{Ar}$ & 12 & 24.1 & 7.65 & 6.88 & 4.3 & 4.5 \\
\hline & $\mathrm{Ca}$ & 11 & $14.4^{\mathrm{x}}$ & $6.10^{x}$ & 5.45 & 4.8 & 4.5 \\
\hline & $\mathrm{Va}$ & 10 & 12.4 & 6.06 & 5.15 & 4.7 & 4.9 \\
\hline & $\mathrm{Ar}$ & 12 & 20.3 & 8.32 & $5.12^{\mathrm{x}}$ & 4.2 & 4.8 \\
\hline & $\mathrm{CP}$ & 12 & 17.3 & $7.53^{y}$ & $4.87^{x}$ & 5.0 & 5.0 \\
\hline \multirow[t]{4}{*}{ 'Redspire'/Rd } & $\mathrm{AB}$ & 12 & 18.5 & $7.84^{y}$ & 7.89 & 4.6 & 4.2 \\
\hline & $\mathrm{Ar}, \mathrm{CS}$ & 12 & $19.8^{y}$ & 9.45 & 7.13 & 4.5 & 4.6 \\
\hline & $\mathrm{Ar}$ & 12 & $15.1^{\mathrm{x}}$ & 8.38 & 5.66 & 4.8 & 4.7 \\
\hline & $\mathrm{Va}$ & 12 & $16.2^{y}$ & $8.16^{\mathrm{y}}$ & $4.81^{\mathrm{x}}$ & 4.7 & 4.9 \\
\hline \multirow[t]{2}{*}{ 'Whitehouse'/Wh } & CS & 12 & 18.1 & $8.08^{x}$ & 5.51 & $3.8^{\mathrm{x}}$ & 4.0 \\
\hline & $\mathrm{Br}$ & 12 & $19.4^{\mathrm{x}}$ & 8.54 & $6.43^{\mathrm{x}}$ & $3.5^{\mathrm{x}}$ & 4.1 \\
\hline \multirow[t]{2}{*}{ Valiant $^{\circledR} / \mathrm{Va}$} & $\mathrm{CS}$ & 10 & 12.7 & 6.00 & 5.58 & 4.7 & 4.8 \\
\hline & $\mathrm{Rd}$ & 12 & $14.1^{\mathrm{x}}$ & $7.31^{\mathrm{x}}$ & $6.34^{\mathrm{y}}$ & 4.3 & 4.8 \\
\hline
\end{tabular}

${ }^{\mathrm{z}}$ Average trunk diameter, tree height, and crown width are in the most advanced year; foliage health and branch health ratings are averaged over all years: 1 , $2,3,6,9$, and 12 in most cases.

${ }^{\mathrm{y}}$ Significantly greater at $95 \%$ level than corresponding value of the paired cultivar.

${ }^{\mathrm{x}}$ Significantly smaller at $95 \%$ level than corresponding value of the paired cultivar. Foliage and branch health ratings: $1=65 \%$ to $100 \%$ of leaves or branches exhibit injury, $2=45 \%$ to $60 \%, 3=25 \%$ to $40 \%, 4=5 \%$ to $20 \%, 5=$ less than $5 \%$. 


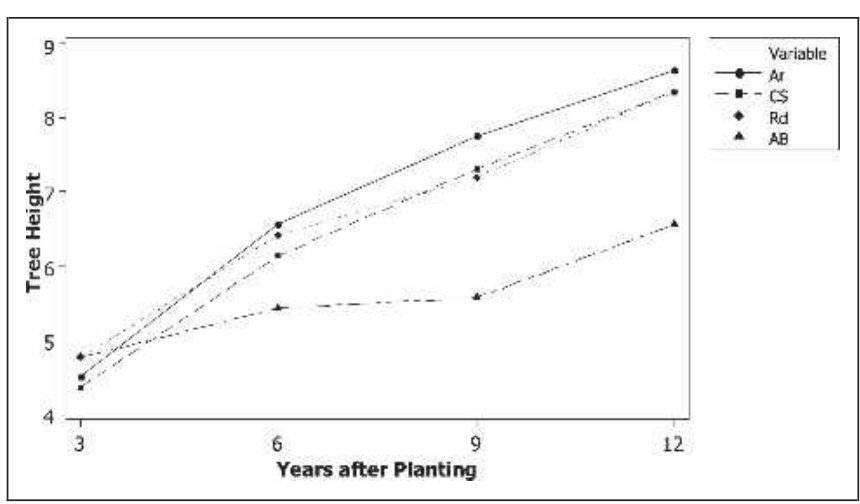

Figure 1. Heights $(\mathrm{m})$ of cultivars 3 to 12 years after planting. Ar = Aristocrat; $\mathrm{CS}=$ Cleveland Select; $\mathrm{Rd}=\mathrm{Red}$ spire; $A B=$ Autumn Blaze.

and $6 \mathrm{~m}$ (16.5 to $19.8 \mathrm{ft})$. Cleveland Pride ${ }^{\circledR}$, Valiant ${ }^{\circledR}$, and 'Whitehouse' were as narrow as 'Cleveland Select' until the 9th year but afterward spread out much more.

Trunk diameters at a height of $1.35 \mathrm{~m}(4.5 \mathrm{ft})$ varied considerably among communities. Aristocrat ${ }^{\mathrm{TM}}$ had the largest trunk diameters, but trunks of all cultivars were sturdy enough to provide good support.

The foliage and branches of all but one of the cultivars remained healthy throughout the 12 years as indicated by ratings above 4.0. The one minor exception was the foliage of 'Whitehouse' at both locations where it was planted. Anthracnose or fireblight were suspected causes of injuries to leaves but were not verified. Fireblight can be serious in southern states (Fare et al. 1991) but was not a problem in this study.

Two undesirable characteristics of Callery pears that have been reported elsewhere did not affect the trees in the performance tests. No breakage or tearing out of branches was reported, although it is known that severe damage to branches and trunks can occur when heavy snow or ice accumulates on

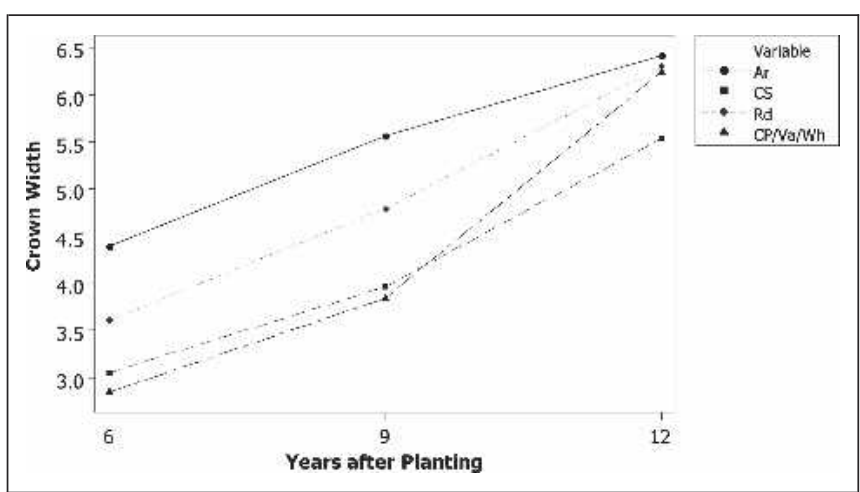

Figure 2. Crown widths $(m)$ of cultivars 6 to 12 years after planting. $\mathrm{Ar}=$ Aristocrat; $\mathrm{CS}=$ Cleveland Select; $\mathrm{Rd}=$ redspire; $\mathrm{AB}=$ Autumn Blaze; $\mathrm{CP}=$ Cleveland Pride; $\mathrm{Va}=$ Valiant; $W h=$ Whitehouse. leaves before they are shed late in the fall, often aggravated by wind. Nor was any indication of invasiveness reported, although there were grassy areas adjacent to some of the plots where seedlings could grow.

\section{CONCLUSIONS}

All of the Callery pear cultivars that were evaluated for 12 years performed well as street trees, although the likelihood of breakage by storms in the future could cause some to be less desirable than others. Some were distinctive in height or crown spread. 'Autumn Blaze' was somewhat shorter than others, and 'Cleveland Select' was narrower. The latter, also known as 'Chanticleer' pear, was selected as the 2005 Urban Tree of the Year by the Society of Municipal Arborists (2004). All of the Callery pears were still growing in height at the 12th year, and most of them were already interfering with utility wires, so none of the tested cultivars should be planted below overhead wires.

Acknowledgments. Financial support for the Municipal Tree Restoration Program was provided by Allegheny Energy, Asplundh Tree Expert Co., Baltimore Gas \& Electric, Bartlett Tree Expert Co., Duquesne Light, Environmental Consultants Inc., FirstEnergy Corp., Hazlett Tree Service, PECO Energy Company, PPL Electric Utilities, and UGI Utilities. Service foresters of the Pennsylvania Bureau of Forestry and extension urban foresters of Penn State University assisted with the measurements.

\section{LITERATURE CITED}

Fare, D.C., C.H. Gilliam, and H.G. Ponder. 1991. Fireblight susceptibility, growth and other characteristics in ornamental pears in Alabama. Journal of Arboriculture 17: 257-260.

Gerhold, H.D. 2000. Callery pear cultivars tested as street trees: Second report. Journal of Arboriculture 26:55-59.

Gerhold, H.D., and H.L. McElroy. 1994. Callery pear cultivars tested as street trees: Initial results. Journal of Arboriculture 20:259-261.

Haserodt, H., and T.D. Sydnor. 1983. Growth habits of five cultivars of Pyrus calleryana. Journal of Arboriculture 9: 160-163.

Kuser, J.E., G. Robinson, and N. Polarin. 2001. Four-year evaluation of five cultivars of Pyrus calleryana. Journal of Arboriculture 27:88-91.

Society of Municipal Arborists. 2004. 2005 urban tree of the year, 'Chanticleer' pear. City Trees 40:34-38.

Henry D. Gerhold

Professor of Forest Genetics

School of Forest Resources

Penn State University

333 Forest Resources Building

University Park, PA 16801, U.S.

hdg@psu.edu 
Résumé. Les coopérants du Programme municipal de restauration des arbres ont plantés neuf cultivars de poiriers (Pyrus calleryana Decne.) dans 11 municipalités de Pennsylvanie afin de les évaluer comme arbres de rue, et ce à raison de deux cultivars (trois dans un cas) dans chaque communauté. Les coopérants ont mesurés ces arbres annuellement avec des méthodes standardisées durant trois ans, et par la suite à intervalles de trois ans jusqu'à la douzième année. Les différences les plus significatives se sont produit en regard de la hauteur de l'arbre et de largeur de la cime. Les plus grands ont été les cultivars 'Aristocrat', 'Clevelend Select' et 'Redspire' qui ont atteints plus de $8 \mathrm{~m}$ en moyenne en 12 ans, et même 10,3 m dans une municipalité. 'Autum Blaze', évalué à un seul endroit, était environ 1,5 à $2 \mathrm{~m}$ plus petit après 12 ans. Les hauteurs des autres cultivars testés à un seul ou deux endroits étaient similaires à celles des plus grands. Les différences en regard de la largeur des cimes étaient plus importantes lors des neuf premières années que lors de la douzième où les arbres avaient une largeur moyenne 6,5 m. Les cultivars Cleveland Pride ${ }^{\circledR}$, 'Cleveland Select', Valiant ${ }^{\circledR}$ et 'Whitehouse' étaient plus étroits que les autres jusqu'à la neuvième année, mais seulement 'Cleveland Select' à 5,6 m est demeuré plus étroit à la douzième année, et pas partout. Tous les cultivars sont demeurés en bonne santé durant toute la période, et ce même si le feuillage de 'Whitehouse' a montré des symptômes mineurs de blessures durant plusieurs années. Comme arbres de rues, les poiriers n'étaient pas invasifs et non pas non plus soufferts de bris de branches qui peuvent s'avérer un problème sérieux. Tous les cultivars sont trop grands pour être plantés sous des réseaux électriques.

Zusammenfassung. Die Mitarbeiter des Programms für Baumneupflanzungen pflanzten neun Birnen-Kultivare (Pyrus calleryana Decne.) in elf Gemeinden in Pennsylvanien, um sie als Straßenbäume durch den Vergleich von zwei Kultivaren (drei in einem Fall) in jeder Gemeinde zu bewerten. Die Mitarbeiter vermassen sie jährlich über eine Zeitraum von drei Jahren mit standardisierten Methoden und folgend in einem dreijährigen Intervall bis zum zwölften Jahr. Die auffälligsten Unterschiede traten bei der Höhe und Kronenbreite auf. Die größten waren Aristocrat, Cleveland und Redspire, die mehr als $8 \mathrm{~m}$ im Durchschnitt bis zum zwölften Jahr erreichten, sogar 10,3 m in einer Kommune. Autumn Blaze, der nur in einer Gemeinde bewertet wurde, erreichte 1,5-2 m weniger im zwölften Jahr. Die Höhen der anderen Kultivare, an ein bis zwei Standorten getestet, waren ähnlich den größten. Die Kronenbreite variierte mehr in den ersten neune Jahren als bis zum zwölften Jahr, wo der Durchschnitt 6,5 m betrug. Cleveland Pride, Cleveland Select, Valiant und Whithouse waren schmaler als die anderen bis zum neunten Jahr, aber nur Cleveland Select blieb mit 5,6 m schmal bis ins zwölfte Jahr, und nicht überall. Alle Kultivare waren während der ganzen Periode, obwohl das Laub von Whitehouse in vielen Jahren kleine Verletzungen erlitt. Als Straßenbäume sind die Birnen nicht sehr invasiv und leiden nicht unter Astbruch, was ein ernstes Problem werden kann. Alle Kultivare sind zu groß, um unter Elektroleitungen gepflanzt zu werden.

Resumen. Los cooperadores en el Programa Municipal de Restauración de Árboles plantaron 9 cultivares de perales (Pyrus calleryana Decne.) en 11 comunidades de Pennsylvania para la evaluación como árboles urbanos, comparando 2 cultivares (3 en un caso) en cada comunidad. Los cooperadores los midieron manualmente con métodos estandarizados por tres años, y a intervalos de tres años hasta el $12^{\text {th }}$ año. Las diferencias más notables ocurrieron en altura y diámetro de la copa de los árboles. Los más altos fueron Aristocrat $^{\mathrm{TM}}$, 'Cleveland Select', y 'Redspire', alcanzando más de 8 m (26 pies) en promedio para el doceavo año, aunque alcanzaron $10.3 \mathrm{~m}$ (34 pies) en una comunidad. 'Autumn Blaze', evaluado solamente en una localidad, estuvo cerca de $1 \frac{1}{1 / 2}$ a $2 \mathrm{~m}$ ( 5 a 6.5 pies) más pequeño en el $12^{\text {th }}$ año. Las alturas de los otros cultivares, probados en solo una o dos localidades, fueron similares a los más grandes. Los diámetros de las copas difirieron más en los primeros nueve años que en el doceavo, cuando en promedio la mayoría estuvieron cerca de $6.5 \mathrm{~m}$ (21 pies) de diámetro. Cleveland Pride ${ }^{\circledR}$, 'Cleveland Select', Valiant@, y 'Whitehouse' fueron más estrechos de copa que los otros hasta el noveno año, pero solamente 'Cleveland Select' en cerca de 5.6 m (18.4 pies) permaneció más estrecho en el doceavo año, y no en todos los sitios. Todos los cultivares estuvieron bien de salud durante el período completo, a pesar de que el follaje de 'Whitehouse' exhibió menores daños en muchos años. Como árboles urbanos los perales no fueron invasivos, y no sufrieron rompimiento de ramas, lo cual puede convertirse en un problema serio. Todos los cultivares crecen demasiado altos para ser plantados bajo líneas aéreas. 